\title{
Front Matter: Volume 8524
}

, "Front Matter: Volume 8524," Proc. SPIE 8524, Land Surface Remote Sensing, 852401 (1 July 2013); doi: 10.1117/12.2008672

SPIE. Event: SPIE Asia-Pacific Remote Sensing, 2012, Kyoto, Japan 


\title{
PROCEEDINGS OF SPIE
}

\section{Land Surface Remote Sensing}

\author{
Dara Entekhabi \\ Yoshiaki Honda \\ Haruo Sawada \\ Jiancheng Shi \\ Taikan Oki \\ Editors
}

\section{October-2 November 2012 \\ Kyoto, Japan}

Sponsored by

SPIE

\section{Cosponsored by}

JAXA-Japan Aerospace Exploration Agency (Japan) • NASA-National Aeronautics and Space Administration (United States) • National Institute of Information and Communications Technology (Japan) • Commemorative Organization for the Japan World Exposition (Japan) • ISRO—Indian Space Research Organization (India) • State Key Laboratory of Remote Sensing Science (China)

Cooperating Organizations

ISPRS-International Society for Photogrammetry and Remote Sensing

\section{Supported by}

Japan Society of Atmospheric Environment • Japan Society of Photogrammetry and Remote Sensing Laser Radar Society of Japan • Meteorological Society of Japan • Optical Society of Japan Society of Environmental Science, Japan - Society of Geomagnetism and Earth, Planetary and Space Sciences • The Astronomical Society of Japan • The Geodetic Society of Japan • The Institute of Electrical Engineers of Japan The Institute of Electronics, Information and Communication Engineers • The Japan Society of Applied Physics • The Laser Society of Japan • The Remote Sensing Society of Japan • The Society of Instrument and Control Engineers • The Spectroscopical Society of Japan

Published by

SPIE

\section{Volume 8524}


The papers included in this volume were part of the technical conference cited on the cover and title page. Papers were selected and subject to review by the editors and conference program committee. Some conference presentations may not be available for publication. The papers published in these proceedings reflect the work and thoughts of the authors and are published herein as submitted. The publisher is not responsible for the validity of the information or for any outcomes resulting from reliance thereon.

Please use the following format to cite material from this book:

Author(s), "Title of Paper," in Land Surface Remote Sensing, edited by Dara Entekhabi,

Yoshiaki Honda, Haruo Sawada, Jiancheng Shi, Taikan Oki, Proceedings of SPIE Vol. 8524 (SPIE, Bellingham, WA, 2012) Article CID Number.

ISSN: 0277-786X

ISBN: 9780819492630

Published by

SPIE

P.O. Box 10, Bellingham, Washington 98227-0010 USA

Telephone +1 3606763290 (Pacific Time) · Fax +1 3606471445

SPIE.org

Copyright (@ 2012, Society of Photo-Optical Instrumentation Engineers.

Copying of material in this book for internal or personal use, or for the internal or personal use of specific clients, beyond the fair use provisions granted by the U.S. Copyright Law is authorized by SPIE subject to payment of copying fees. The Transactional Reporting Service base fee for this volume is $\$ 18.00$ per article (or portion thereof), which should be paid directly to the Copyright Clearance Center (CCC), 222 Rosewood Drive, Danvers, MA 01923. Payment may also be made electronically through CCC Online at copyright.com. Other copying for republication, resale, advertising or promotion, or any form of systematic or multiple reproduction of any material in this book is prohibited except with permission in writing from the publisher. The CCC fee code is 0277-786X/12/\$18.00.

Printed in the United States of America.

Publication of record for individual papers is online in the SPIE Digital Library.

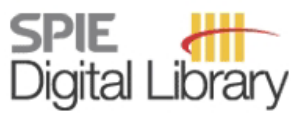

SPIEDigitalLibrary.org

Paper Numbering: Proceedings of SPIE follow an e-First publication model, with papers published first online and then in print and on CD-ROM. Papers are published as they are submitted and meet publication criteria. A unique, consistent, permanent citation identifier (CID) number is assigned to each article at the time of the first publication. Utilization of CIDs allows articles to be fully citable as soon as they are published online, and connects the same identifier to all online, print, and electronic versions of the publication. SPIE uses a six-digit CID article numbering system in which:

- The first four digits correspond to the SPIE volume number.

- The last two digits indicate publication order within the volume using a Base 36 numbering

system employing both numerals and letters. These two-number sets start with 00, 01, 02, 03, 04, 05, 06, 07, 08, 09, 0A, OB ... 0Z, followed by 10-1Z, 20-2Z, etc.

The CID Number appears on each page of the manuscript. The complete citation is used on the first page, and an abbreviated version on subsequent pages. Numbers in the index correspond to the last two digits of the six-digit CID Number. 


\title{
Contents
}

\author{
ix Conference Committee \\ xi The benefit of space derived geo-spatial information for sustainable development \\ (Keynote Speech) \\ Y. Horikawa, Japan Aerospace Exploration Agency (Japan) \\ xvii JAXA Earth Observation Program update (Plenary Paper) [8523-507] \\ M. Homma, Japan Aerospace Exploration Agency (Japan)
}

\section{SESSION 1 LAND USE AND LAND COVER CHANGE}

852404 Mapping fifty global cities' growth using time-series Landsat data [8524-3]

H. Bagan, Y. Yamagata, National Institute for Environmental Studies (Japan)

852406 Polarimetric analysis of coastal region using time series of Radarsat-2 images [8524-5]

H.-W. Wang, K.-S. Chen, National Central Univ. (Taiwan); H.-R. Liao, National Science

Council (Taiwan)

852407 Validation of the wetlands map derived from MODIS imagery in North America [8524-6]

G. Tana, Chiba Univ. (Japan); H. Letu, Tokai Univ. (Japan); R. Tateishi, Chiba Univ. (Japan)

852408 Land cover classification comparisons among dual polarimetric, pseudo-fully polarimetric, and fully polarimetric SAR imagery [8524-7]

B. Mishra, J. Susaki, Kyoto Univ. (Japan)

852409 A compound method for automatically extracting plateau wetlands from satellite imagery [8524-8]

H. Li, Hohai Univ. (China); J. Gao, The Univ. of Auckland (New Zealand)

\section{SESSION 2 WATER CYCLE}

$8524 \mathrm{OE}$ Analyzing the inundation patterns in Asia floodplains by passive microwave data [8524-37] H. Shang, State Key Lab. of Remote Sensing Science (China) and Technische Univ. Delft (Netherlands); L. Jia, Alterra B.V. (Netherlands) and State Key Lab. of Remote Sensing Science (China); M. Menenti, Technische Univ. Delft (Netherlands)

8524 OG Airborne active and passive L-band measurements using PALS instrument in SMAPVEX12 soil moisture field campaign [8524-20]

A. Colliander, S. Yueh, S. Chazanoff, S. Dinardo, I. O'Dwyer, Jet Propulsion Lab. (United States); T. Jackson, U.S. Dept. of Agriculture (United States); H. McNairn, Agriculture and Agri-Food Canada (Canada); P. Bullock, Univ. of Manitoba (Canada); G. Wiseman, Agriculture and Agri-Food Canada (Canada); A. Berg, Univ. of Guelph (Canada); R. Magagi, Univ. of Sherbrooke (Canada); E. Njoku, Jet Propulsion Lab. (United States) 
$8524 \mathrm{Ol} \quad$ Monitoring surface climate with its emissivity derived from satellite measurements [8524-22] D. K. Zhou, A. M. Larar, X. Liu, NASA Langley Research Ctr. (United States)

$85240 \mathrm{~J}$ Estimation and monitoring heat discharge rates using Landsat ETM+ thermal infrared data: a case study in Unzen geothermal field, Kyushu, Japan [8524-23]

M. B. Mia, Kyushu Univ. (Japan) and Univ. of Dhaka (Bangladesh); Y. Fujimitsu, Kyushu Univ. (Japan); C. J. Bromely, GNS Science (New Zealand)

8524 OK Estimation of global ET-Index from satellite imagery for water resources management [8524-24]

M. Tasumi, Univ. of Miyazaki (Japan); R. Kimura, Tottori Univ. (Japan); M. Moriyama, Nagasaki Univ. (Japan); R. G. Allen, Univ. of Idaho (United States); A. Fujii, Univ. of Miyazaki (Japan)

$8524 \mathrm{OL}$ Semi-analytical land surface temperature estimation algorithm for GCOM-C/SGLI [8524-25] M. Moriyama, Nagasaki Univ. (Japan)

8524 OM Remote sensing based continuous estimation of regional evapotranspiration by improved SEBS model [8524-26]

H. Chen, D. Yang, Tsinghua Univ. (China)

852400 Regression imputation with ground air temperature for the satellite-based lake and reservoir temperature database in Japan [8524-29]

H. Tonooka, Ibaraki Univ. (Japan)

$85240 Q \quad$ Analysis of microwave backscatter measured by radar altimeter on land to study surface aerodynamic roughness [8524-31]

L. Yang, Q. Liu, State Key Lab. of Remote Sensing Science (China)

8524 OT A decadal observation of vegetation dynamics using multi-resolution satellite images [8524-34]

Y.-S. Chiang, K.-S. Chen, C.-J. Chu, National Central Univ. (Taiwan)

$8524 \mathrm{OW}$ On the high-fidelity monitoring of $\mathrm{C}_{3}$ and $\mathrm{C}_{4}$ crops under nutrient and water stress [8524-38]

G. V. G. Baranoski, T. F. Chen, B. W. Kimmel, E. Miranda, D. Yim, Univ. of Waterloo (Canada)

8524 OX Isolated tree 3D modeling: based on photographing leaf area density (LAD) calculation and L-system method [8524-39]

S. Jin, M. Tamura, Kyoto Univ. (Japan)

\section{SESSION 5 DISASTERS AND HAZARDS}

$85240 Z$ Detection of three-dimensional crustal movements due to the 2011 Tohoku, Japan earthquake from TerraSAR-X intensity images [8524-41]

W. Liu, F. Yamazaki, Chiba Univ. (Japan); T. Nonaka, T. Sasagawa, PASCO (Japan) 
852410 Monitoring southwest drought of China using HJ-1A/B and Landsat remote sensing data [8524-42]

H. Huang, H. Zhou, P. Wang, W. Wu, S. Yang, National Disaster Reduction Ctr. of China

(China) and Satellite Disaster Reduction Application Ctr. Of China (China)

852411 Detecting damage to coastal forests caused by the Tohoku earthquake in Japan using time-series remote sensing images [8524-43]

E. Kodani, K. Nakamura, Tohoku Research Ctr. (Japan); T. Sakamoto, Forestry and Forest Products Research Institute (Japan); K. Kimura, Aomori Prefectural Industrial Technology Research Ctr. (Japan)

852412 Detection of damaged buildings using GeoEye-1 imagery and airborne lidar data: a case study on the 2011 Tohoku earthquake [8524-44]

Y. Yamamoto, Aichi Institute of Technology (Japan); T. Asaka, S. Aoyama, K. Iwashita,

K. Kudou, Nihon Univ. (Japan)

852414 A framework for diagnosis of environmental health based on remote sensing [8524-46] C. Cao, M. XU, State Key Lab. of Remote Sensing Science (China); W. Chen, R. Tian, State Key Lab. of Remote Sensing Science (China) and Graduate School of the Chinese Academy of

852415 Semi-automatic recognition and mapping of event-induced landslides by exploiting multispectral satellite images and DEM in a Bayesian framework [8524-47]

A. C. Mondini, Consiglio Nazionale delle Ricerche (Italy) and Univ. degli Studi di Perugia (Italy); K. Chang, Kainan Univ. (Taiwan); M. Rossi, Consiglio Nazionale delle Ricerche (Italy) and Univ. degli Studi di Perugia (Italy); I. Marchesini, F. Guzzetti, Consiglio Nazionale delle Ricerche (Italy)

852416 Damage estimation of the Great East Japan Earthquake by NICT airborne SAR (PI-SAR2) [8524-48]

M. Satake, T. Kobayashi, J. Uemoto, T. Umehara, S. Uratsuka, National Institute of Information and Communications Technology (Japan)

85241 A Assessing the sensitivity of two new indicators of vegetation response to water availability for drought monitoring [8524-52]

L. Jia, Alterra (Netherlands) and State Key Lab. of Remote Sensing Science (China);

G. Hu, J. Zhou, State Key Lab. of Remote Sensing Science (China); M. Menenti, Technische Univ. Delft (Netherlands) and State Key Lab. of Remote Sensing Science (China)

8524 ID Study on forest above-ground biomass synergy inversion from GLAS and HJ-1 data [8524-56]

Z. Fang, State Key Lab. of Remote Sensing Science (China) and Graduate School of the Chinese Academy of Sciences (China); C. Cao, W. Ji, M. XU, State Key Lab. of Remote Sensing Science (China); W. Chen, Kyoto Univ. (Japan) 
$8524 \mathrm{lF}$ Mapping Sargassum beds off, ChonBuri Province, Thailand, using ALOS AVNI2 image [8524-58]

T. Noiraksar, Burapha Univ. (Thailand); T. Komatsu, The Univ. of Tokyo (Japan) and CREST

(Japan); S. Sawayama, The Univ. of Tokyo (Japan); S. Phauk, Royal Univ. of Phnom Penh

(Cambodia); K. Hayashizaki, CREST (Japan) and Kitasato Univ. (Japan)

SESSION 7 REMOTE SENSING ANALYSIS AND MODELING

8524 1G Possibility of mutual verification between satellite products and climate model simulation results [8524-59]

K. Mabuchi, Meteorological Research Institute (Japan); Y. Honda, Chiba Univ. (Japan);

K. N. Nasahara, Univ. of Tsukuba (Japan); H. Murakami, M. Hori, Japan Aerospace Exploration Agency (Japan); M. M. Moriyama, Nagasaki Univ. (Japan); A. Ono, Nara Women's Univ. (Japan)

$85241 \mathrm{~J} \mathrm{Parametric} \mathrm{representation} \mathrm{of} \mathrm{soil} \mathrm{isoline} \mathrm{equation} \mathrm{and} \mathrm{its} \mathrm{accuracy} \mathrm{estimation} \mathrm{in} \mathrm{red-NIR}$ reflectance space [8524-63]

K. Taniguchi, Y. Ikuta, Aichi Prefectural Univ. (Japan); K. Obata, Univ. of Hawai'i (United

States); M. Matsuoka, Kochi Univ. (Japan); H. Yoshioka, Aichi Prefectural Univ. (Japan)

8524 IK Influences of band-correlated noise on FVC by VI-isoline based LMM: characteristic behavior of propagated error [8524-64]

Y. Ikuta, K. Taniguchi, Aichi Prefectural Univ. (Japan); K. Obata, Univ. of Hawai'i (Japan);

M. Matsuoka, Kochi Univ. (Japan); H. Yoshioka, Aichi Prefectural Univ. (Japan)

$85241 \mathrm{M}$ Comparison between the research result of mathematical morphology method applied to satellite SAR data and the other reported results for the detection of the 2011 off the Pacific coast of Tohoku Japan earthquake and tsunami-affected farmlands [8524-66]

Y. Yamada, National Agriculture and Food Research Organization (Japan)

8524 IN Supporting elephant conservation in Sri Lanka through MODIS imagery [8524-67]

K. Perera, Univ. of Southern Queensland (Australia); R. Tateishi, Chiba Univ. (Japan)

POSTER SESSION: LAND USE AND LAND COVER CHANGE

8524 1Q Accuracy assessment of land use classification using hybrid methods [8524-70]

K. T. Chang, F. G. Yiu, Minghsin Univ. of Science and Technology (Taiwan); J. T. Hwang, National Taipei Univ. (Taiwan); Y. X. Lin, Minghsin Univ. of Science and Technology (Taiwan)

8524 IR Global land cover classification using annual statistical values [8524-71]

N. Soyama, Tenri Univ. (Japan); K. Muramatsu, Nara Women's Univ. (Japan); M. Daigo,

Doshisha Univ. (Japan)

POSTER SESSION: THERMAL REMOTE SENSING AND EVAPORTRANSPORATION

8524 IV The satellite-based, forest-water stress detection algorithm [8524-78]

S. Tanigawa, M. Moriyama, Nagasaki Univ. (Japan); Y. Honda, K. Kajiwara, Chiba Univ. (Japan) 
$8524 \mathrm{lW}$ The effects of urban stream improving the thermal environment in urban area [8524-79] J. Park, S. Na, J. Park, Chungbuk National Univ. (Korea, Republic of)

$85241 \mathrm{X}$ Retrieval of land surface temperature by cross-calibrated SVISSR thermal infrared data onboard China geostationary satellite [8524-80]

X. Ouyang, State Key Lab. of Remote Sensing Science (China); L. Jia, Alterra (Netherlands) and State Key Lab. of Remote Sensing Science (China)

POSTER SESSION: FOREST AND VEGETATION

8524 IY Radiometric calibration method of the general purpose digital camera and its application for the vegetation monitoring [8524-81]

T. Kenta, M. Masao, Nagasaki Univ. (Japan)

8524 IZ Satellite-based fire detection algorithm for GCOM-C1/SGLI [8524-82]

T. Miura, M. Moriyama, Nagasaki Univ. (Japan)

852420 Exploring optimal design of look-up table for PROSAIL model inversion with multi-angle MODIS data [8524-83]

W. He, H. Yang, J. Pan, P. Xu, Beijing Normal Univ. (China)

$852421 \quad$ Estimation of gross primary production capacity from global satellite observations [8524-84] K. Muramatsu, J. Thanyapraneedkul, Nara Women's Univ. (Japan); S. Furumi, Nara Saho College (Japan); N. Soyama, Tenri Univ. (Japan); M. Daigo, Doshisha Univ. (Japan)

POSTER SESSION: DISASTERS AND HAZARDS

852428 Landslide detection using very high-resolution satellite imageries [8524-90]

Y. Suga, Hiroshima Institute of Technology (Japan); T. Konishi, Nihon CADIC Co., Ltd. (Japan)

852429 Analysis of road damage after a large-scale earthquake using satellite images [8524-91] K. Yamaguchi, H. Saji, Shizuoka Univ. (Japan)

8524 2A Study on the tie point selection for DEM extraction from stereo PRISM images [8524-92]

Y. Kawata, Y. Funatsu, S. Yoshii, K. Takemata, Kanazawa Institute of Technology (Japan)

POSTER SESSION: REMOTE SENSING ANALYSIS AND MODELING

8524 2D A study of BRDF over Tokyo for the spaceborne measurements of atmospheric trace gases [8524-95]

K. Noguchi, Nara Women's Univ. (Japan); A. Richter, J. P. Burrows, Univ. of Bremen

(Germany); H. Irie, Chiba Univ. (Japan); K. Kita, Ibaraki Univ. (Japan)

8524 2E MATLAB toolbox for EnviSAT InSAR data processing, visualization, and analysis [8524-96]

Z. Zhang, Z. Ma, G. Chen, Y. Chen, Y. LU, Nanyang Technological Univ. (Singapore) 
$85242 \mathrm{~F} \quad$ Extraction of road traffic information using satellite images and a three-dimensional digital map [8524-97]

F. Shinmura, H. Saji, Shizuoka Univ. (Japan)

$85242 \mathrm{G}$ Relationship between DMSP/OLS nighttime light and $\mathrm{CO}_{2}$ emission from electric power plant [8524-98]

H. Letu, Tokai Univ. (Japan) and Chiba Univ. (Japan); Y. Bao, Inner Mongolia Normal Univ. (China); G. Tana, Chiba Univ. (Japan); M. Hara, Inner Mongolia Normal Univ. (China) and VTI Research Institute (Japan); F. Nishio, Chiba Univ. (Japan) and Inner Mongolia Normal Univ. (China)

8524 2H Landsat imagery-based water furbidity monitoring in Lake Paldang, Korea [8524-99]

S. Na, J. Park, S. Baek, S. Oh, J. Park, Chungbuk National Univ. (Korea, Republic of)

8524 21 Methane analysis using SCIAMACHY data in permafrost area of China [8524-100]

Y. Cen, T. Wu, H. Zhao, L. Zhang, Institute of Remote Sensing Applications (China)

$85242 \mathrm{~J}$ A study of fraction of absorbed photosynthetically active radiation characteristics based on SAIL model simulation [8524-101]

L. Li, State Key Lab. of Remote Sensing Science (China) and Peking Univ. (China); Y. Du,

Y. Tang, Q. Liu, State Key Lab. of Remote Sensing Science (China)

8524 2K Distribution of solar radiation including slope effect in South Korea [8524-102]

S.-C. Baek, J.-H. Park, S. Na, J.-K. Park, Chungbuk National Univ. (Korea, Republic of)

Author Index 


\title{
Conference Committee
}

\author{
Symposium Chairs
}

Upendra Singh, NASA Langley Research Center

(United States)

Toshio Iguchi, National Institute of Information and

Communications Technology (Japan)

Symposium Cochair

A. S. Kiran Kumar, Space Applications Center (India)

Conference Chairs

Dara Entekhabi, Massachusetts Institute of Technology (United States)

Yoshiaki Honda, Chiba University (Japan)

Haruo Sawada, The University of Tokyo (Japan)

Jiancheng Shi, Institute of Remote Sensing Applications (China)

Taikan Oki, The University of Tokyo (Japan)

Conference Program Committee

Christopher D. Elvidge, National Oceanic and Atmospheric Administration (United States)

Peng Gong, University of California, Berkeley (United States)

Alfredo R. Huete, University of Technology Sydney (Australia)

Koji Kajiwara, Chiba University (Japan)

Joon Kim, Seoul National University (Korea, Republic of)

Masao Moriyama, Nagasaki University (Japan)

Dawen Yang, Tsinghua University (China)

\section{Session Chairs}

Welcome and Plenary Presentations

Upendra N. Singh, NASA Langley Research Center (United States)

Toshio Iguchi, National Institute of Information and Communications

Technology (Japan)

1 Land Use and Land Cover Change

Koji Kajiwara, Chiba University (Japan)

Peng Gong, University of California, Berkeley (United States) 
2 Water Cycle

Taikan Oki, The University of Tokyo (Japan)

Dawen Yang, Tsinghua University (China)

3 Thermal Remote Sensing and Evaportransportation

Jiancheng Shi, Institute of Remote Sensing Applications (China)

Masao Moriyama, Nagasaki University (Japan)

4 Forest and Vegetation I

Haruo Sawada, The University of Tokyo (Japan)

Yoshiaki Honda, Chiba University (Japan)

5 Disasters and Hazards

Joon Kim, Seoul National University (Korea, Republic of)

Yoshiaki Honda, Chiba University (Japan)

6 Forest and Vegetation II

Koji Kajiwara, Chiba University (Japan)

Yoshiaki Honda, Chiba University (Japan)

7 Remote Sensing Analysis and Modeling

Masao Moriyama, Nagasaki University (Japan) 


\title{
The benefit of Space derived Geo-spatial information for Sustainable Development
}

\author{
Yasushi Horikawa \\ Japan Aerospace Exploration Agency (Japan)
}

\begin{abstract}
As Chairman of the UN COPUOS I deal with many problems related to collaboration amongst UN Member States who are attempting to reach consensus on the use of space data technology and applications for the purpose of solving regional or global problems which affect all of humanity and to help sustainable development at a global level.
\end{abstract}

At this time, space science and exploration, Earth observations, climate change research, the sharing of environmental data, disaster mitigation and relief, space surveillance for near earth objects for debris monitoring and awareness are the most demanding fields for international collaboration. I consider the UN COPUOS to be the highest international platform for political, scientific, technical and legal debates connected with space, a platform for negotiations, elaboration and promotion of important international treaties, agreements, UN resolutions and guide-lines for all member states.

The UN COPUOS is at the same time both a reflection and an integration of most global and regional forums of cooperation in the space field. In an era where space is becoming increasingly crowded with new players the need to share a commitment to act responsibly to help prevent mishaps, misperceptions and mistrust has become a must.

In 2011, the United Nations celebrated the fiftieth anniversary of the Committee on the Peaceful Uses of Outer Space and recalled its outstanding achievements in ensuring that outer space was used for peaceful purposes. The declaration of the $50^{\text {th }}$ anniversary expressed deep concerns about the fragility of the space environment, that is, the continuing threat of the impact of space debris. Long term sustainability of space activities is now one of the most challenging topics under discussion at the UN COPUOS and a topic that needs real global cooperation and understanding.

As you know, the primary objective of COPUOS is to maximize the benefits of space science, technology, their applications and to increase coherence, synergy, and international cooperation in space activities at various levels including national, regional, and global instrumental support efforts with special consideration for the needs of developing countries. Aiding this effort, the United States launched the first civilian Earth observation satellite, Landsat-1, on July 23, 1972, an achievement whose $40^{\text {th }}$ year anniversary was celebrated this June at UNCOPUOS. 
As you know, Earth observation from space has become a significant tool to benefit human life by helping illuminate dangers to our societies like global climate change due to global warming and the consequent problems of food security and global health, all of which are interlinked with disasters and poverty.

As such, we need a holistic approach to these problems and concerns in order to make sound long-term decisions for humanity's future. The 1992 Earth summit held in Rio de Janeiro neither recognized nor mentioned the use of such space tools to meet human needs on Earth. In the first draft of the Rio+20 Conference document the word "space" was not mentioned once even though today over $75 \%$ of the world is space-knowledgeable and consumes a large amount of space products and services daily. A timely and adapted integration of remote sensing, satellite telecommunication, and global navigation satellite systems to multi-source geospatial datasets will provide some key factors needed to resolve these difficulties.

With increasing awareness of, and concern for, the environmental impacts on Earth caused by global warming and related climate changes we should recognize the critical importance of monitoring these changes and devise climate change mitigation and adaptation measures. Joint development of interoperable systems to address such issues is an important area for international cooperation. The above circumstances notwithstanding, the collection, analysis and use of available information, including the space-acquired ones, to properly manage our life-support systems has been confirmed in many parts of the world as a necessary starting point on the path towards sustainable development and must be rigorously pursued.

Although the issues relating to Earth observation satellite systems and their information accessibility and data policy are being discussed at the meetings of the Group on Earth Observations (GEO) and the Committee on Earth Observation Satellites (CEOS), due to the global nature of its work COPUOS should also address these data utilization issues and further promote the relevance of research in data analysis and utilization in order to strengthen international cooperation among its member States.

Disasters continuously affect our societies in all parts of the World and demonstrate repeatedly how vulnerable we are against the forces of nature and how important it is to strengthen our ability to mitigate the devastating effects of natural disasters.

Loss of life and property could be diminished if better information were available through improved risk assessment, early warning, and monitoring of disasters. In this regard, the integrated and coordinated use of space technologies and their applications can play a crucial role in supporting disaster management by providing accurate and timely information and communication support. 
After the Earthquake on 11 March 2011, JAXA, the Japanese space agency has been observing and analyzing of the disaster area with the Advanced Land Observing Satellite "Daichi" and other satellites of foreign space agencies. Japan once again thanks you for the kind support and help which came generously from all over the world. We have come to realize the importance of using satellite data for natural disaster preparation and response and we would like to share and reconfirm the importance of constant, regular images taken when disasters occur to compare the affected areas for crisis management and response.

The work currently being carried out by the Scientific and Technical Subcommittee through its Working Group on the Long-term Sustainability of Outer Space Activities is critically important. Its goal is to ensure the safe and sustainable use of outer space over many years by future generations.

To implement a set of practical and prudent measures for enhancing the long-term sustainability of space activities, the Working Group was established to address sustainable space utilization and the support of sustainable development on Earth, space debris, space weather, space operations, tools to support collaborative space situational awareness, regulatory regimes, and guidance for actors in the space arena. This is a remarkable undertaking with the objective to identify and examine a wide range of issues and concerns for the long term sustainability of space activities and to prepare a consolidated set of practices and operating procedures and guidelines.

The space environment is quite different from conditions on the ground and air because the position of a space vehicle cannot be easily changed since its movement or orbital behaviour is strictly constrained to the orbit onto which it has been launched. Given how congested the space environment is with satellites, the condition is being exacerbated further by a large amount of space debris. Space utilization for nations involved could become unnecessarily constrained unless the operations of all space vehicles and other space objects are well managed.

The role of international organizations and other entities in the space field continues to be of major importance to our common goal of promoting space activities at the national, regional, interregional and global level. I would like to underline the particular role of regional mechanisms in providing platforms for enhanced coordination and cooperation between space faring nations and emerging space nations and in establishing partnerships between users and providers of space-based services. In this regard I am pleased to note the activities, programs, projects and strategies being performed and developed through the African Leadership Conference on Space Science and Technology for Sustainable Development (ALC); the Asia-Pacific Regional Space Agency Forum (APRSAF); the Asia-Pacific Space Cooperation Organization (APSCO); and the Space Conference of the Americas. 
There is a need to strengthen international collaboration and support for data sharing and access to geospatial information which is expected to be useful in addressing the climate change associated with global warming, carbon cycles, water cycles, as well as human health, food security relating to agriculture and fisheries, and natural disasters.

More specifically, actions undertaken by the regional centers for space science and technology education affiliated with the United Nations could further advance the promotion of data utilization and relevant scientific research. The regional centers have firmly established infrastructures for advanced training in the field of space science and technology, and their long-standing education programmes have been highly successful. Likewise, the network of UN-SPIDER Regional Support Offices around the world caters to the regional coordination of efforts in the area of disaster risk reduction.

Today, various kinds of applications such as those for scientific observation missions, Earth resources observation, as well as educational and capacity building activities are being planned and carried out by an increasing number of governmental and non-governmental entities.

The operation of satellites, for example, gives rise to matters that could be further explored and discussed such as responsibility and liability under the legal regime on outer space. The application of the concept of the launching state in national regulatory frameworks, registration and notification measures, and the continuing development of national regulatory frameworks, as well as guidance to space actors should be understood. Even satellites launched for educational or training purposes should follow international regimes for registration, frequency coordination and liability for damages. In this regard, satellite should be designed for a certain level of reliability. To comply with this, it should be recommended that all satellite programs be reviewed by experts who have substantial experiences in this field.

Space technology provides a wide range of essential tools for making informed decisions in support of development at local, national, regional and global levels in both public and private domains. Information generated from space-derived geospatial data is indispensable in areas such as agriculture, climate change, forestry, public health, disasters, food security, land management, and urban growth. A continuous monitoring and observation system that feeds into decision support systems and ensures an informed decision-making process is crucial. There is a need to ensure a clear view of the planet's status at near real-time and at any given moment. The practical benefits of space technology applications today touch virtually every human endeavor extending across communication, navigation, meteorology, education, health, agriculture, resource management, 
environmental protection and disaster management. To adapt to emerging and future challenges to the global community, the United Nations system, in close coordination with its Member States, needs to find effective solutions to current and emerging global problems.

The United Nations System Task Team on the Post-2015 UN Development Agenda has presented its report to the Secretary-General of the United Nations entitled "Realizing the Future We Want for All". This is a comprehensive assessment of the overall involvement of the UN system and the report will be part of the process leading up to 2015. There are many areas covered in the report where spacebased technologies and data are of crucial importance. In direct relation to space tools, I would like to bring to your attention to the scientific understanding of space environments, as well the importance of improved access to geographical information and geospatial data for more accurate environmental and social impact assessments and more informed decision-making at all levels.

The formulation and implementation of sustainable development policies can succeed only with accurate information concerning the Earth system which today's highly accurate satellites can provide. To be able to gauge and manage societal impacts on our planet, the global community will continue to require consistent and accurate information that can be used to measure such impacts. As an enabler of informed decision-making at all levels of society, space acquired data can produce a shared vision and understanding which in turn can produce joint action. The millennium development goals (MDG) belong to this category of actions which, if attained, can foster global yearning for sustainable development. 
Proc. of SPIE Vol. 8524 852401-16

Downloaded From: https://www.spiedigitallibrary.org/conference-proceedings-of-spie on 26 Apr 2023 Terms of Use: https://www.spiedigitallibrary.org/terms-of-use 